\title{
Pengembangan Multimedia Pembelajaran IPA untuk Meningkatkan Hasil Belajar
}

\author{
Okta Nivia Faizah \\ Universitas Pendidikan Ganesha, Singaraja \\ okta.nivia.faizah@undiksha.ac.id
}

I Gde Wawan Sudatha

Universitas Pendidikan Ganesha, Singaraja e-mail:igdewawans@undiksha.ac.id

\author{
Alexander Hamonangan Simamora \\ Universitas Pendidikan Ganesha, Singaraja \\ e-mail: alexander.simamora@undiksha.ac.id
}

\begin{abstract}
Abstrak
Permasalahan penelitian ini kurangnya media pembelajaran yang membantu proses pembelajaran sehingga siswa kesulitan memahami materi yang disampaikan guru.Tujuan penelitian ini adalah (1) mendeskripsikan proses pengembangan multimedia pembelajaran pada mata pelajaran IPA, (2 )menguji kualitas multimedia pembelajaran pada mata pelajaran IPA, (3) mengetahui efektifitas multimedia pembelajaran mata pelajaran IPA. Metode pengumpulan data menggunakan metode observasi,wawancara,kuesioner,dan tes. Analisis data menggunakan analisis deskriptif kualitatif, kuantitatif dan statistik inferensial/uji-t. Proses pengembangan multimedia pembelajaran menggunakan model Luther meliputi 6 tahapan.Validasi multimedia dilakukan oleh ahli isi mata pelajaran, ahli media pembelajaran, uji coba perorangan oleh 6 orang siswa, uji coba kelompok kecil oleh 3 orang siswa, dan uji coba lapangan oleh 22 orang siswa. Hasil penelitian ini adalah (1) proses pengembangan multimedia pembelajaran mulai dari langkah analisis, desain, pengumpulan bahan,pembuatan,penyelesaian,dan distribusi; (2) kualitas hasil pengembangan media menurut review ahli dan siswa yaitu: a) ahli isi pembelajaran 94\%(sangat baik);b)ahli media pembelajaran $86 \%$ (baik);c) uji coba perorangan 94,9\%(sangat baik); d)uji coba kelompok kecil 91,9\%(sangat baik);e)uji coba lapangan $92 \%$ (sangat baik); (3) Multimedia pembelajaran ini efektif untuk meningkatkan hasil belajar IPA.
\end{abstract}

Kata kunci: IPA, multimedia, pengembangan.

\begin{abstract}
the problem of this study is the lack of learning media so that students have difficulty in understanding the material presented by the teacher.This study aims to describe the development process of multimedia learning in science subject,testing the quality of multimedia learning and find out the effectiveness of multimedia learning.Data collection used are observation method,interviews, questionnaires and test.Furthermore, the data analysis adopt descriptive qualitative approach,quantitative, inferential statistic/t-test. The process of developing multimedia learning using Luther model which includes 6 steps. They were analysis,design,collecting material,processing,finishing and distribution.Multimedia validation carried out by the expert,instructional media experts,individual trial,small group trials and field trials.Individual trials conducted by 3 students while the small group trials were conducted by 6 students and field trials conducted by 22 students. This study found that developing process of multimedia learning starts from analysis,design,collecting materials,processing,finishing and distribution.Next,result quality of multimedia learning development according to experts and student reviews:a)learning expert $94 \%$ are in very good category;b)learning media expert $86 \%$ are in good category;c)individual trials $94,9 \%$ are in very good category;d)small group trials $91,9 \%$ are in very good category,e)field trial $92 \%$ are in very good category.Last,This learning multimedia is effective to improve science learning outcomes.
\end{abstract}

Keywords: Luther, multimedia learning, science, development.

\section{Pendahuluan}

Pendidikan ialah sebuah kebutuhan bagi manusia dalam menjalani kehidupan. Pendidikan dapat mendorong peningkatan kualitas manusia dalam membentuk peningkatan kompetensi kognitif, afektif, maupun psikomotor. Namun, masalah yang dihadapi dalam upaya memperbaiki dan meningkatkan karena dalam hal ini sangat kompleks. Banyak faktor yang dipertimbangkan karena dalam hal ini perlu disadari bahwa, pendidikan ialah salah satu faktor yang dapat meningkatkan kualitas sumber daya manusia satu bangsa. Bagi suatu bangsa pendidikan manusia menjadi lebih mampu beradaptasi dengan lingkungan. Dengan dinamika pendidikan akan mampu mengantisipasi berbagai kemungkinan yang akan terjadi. 
Dimyati(1999:157) menyatakan, peran teknologi informasi dalam pembelajaran ini selain dapat membantu peserta didik dalam hal belajar, juga berpengaruh kepada guru terutama dalam memanfaatkan fasilitas untuk kepentingan memperkaya kemampuan mengajarnya.

Wiana(2018:2) menyatakan, penggunaan media saat pembelajaran dapat memberikan banyak manfaat bagi preoses pembelajaran. Astuti (2018:2) menyatakan, salah satu faktor yang dapat membuat proses pembelajaran akan efektif adalah media. Terdapat manfaat proses pembelajaran dapat meningkatkan keinginan dan minat baru pada saat menggunakan media pembelajaran, dan sehingga mempengaruhi psikologi terhadap siswa.

Pembelajaran adalah kegiatan dimana guru melakukan peranan-peranan tertentu agar siswa dapat belajar untuk mencapai tujuan pembelajaran yang diharapkan.Terdapat berbagai konsepsi tentang pembelajaran, hal ini terjadi karena adanya perbedaan pendekatan yang digunakan seseorang saat memahami makna pembelajaran.Pembelajaran yang baik adalah pembelajaran yang kreatif, inovatif dan produktif. Sutirman (2013:23) menyatakan bahwa "Pembelajaran kreatif, inovatif dan produktif adalah pembelajaran yang menciptakan kondisi agar siswa melakukan proses berfikir untuk menemukan gagasan-gagasan unik, dan manfaatkan gagasan tersebut menjadi ide-ide yang memiliki nilai lebih, sehingga dihasilkan karya yang nyata dan berguna".

Multimedia pembelajaran merupakan penggabungan antara gambar teks, grafik, audio, dan video dengan menggabungkan link dan tool, serta navigasi untuk mendukung proses pembelajaran. Istilah multimedia pembelajaran umumnya menunjuk pada semua software pendidikan yang diakses melalui komputer dimana siswa dapat berinteraksi dengannya.Tetapi masih perlu pengembangan multimedia yang baik untuk pembelajaran. Multimedia memiliki tiga fungsi dalam pembelajaran yaitu mengambil perhatian, presentasi dan latihan.

Tidak terdapat batasan durasi dalam multimedia, tetapi dalam mengambil perhatian siswa dalam pembelajaran, durasi multimeida sebaiknya dibatasi. Cara untuk membatasi durasi multimedia yaitu menggabungkan multimedia dengan microlearning. Microlearning merupakan pembelajaran berdurasi singkat dengan satu sasaran spesifik dan sifatnya konseptual, karena microlearning memiliki tujuan pembelajaran yang spesifik terhadap suatu kinerja yang dicapai.

Pembelajaran yang kurang menarik wajar dirasakan para guru yang belum memahami kebutuhan siswa baik dari karakteristik, maupun dalam mengembangkan ilmu. Peran guru sangatlah penting untuk memilih dan melaksanakan pembelajaran berbasis konvesional. Pembelajaran yang dikatakan baik dapat dilihat dari suasana pembelajaran yang kondusif serta hubungan komunikasi antara guru dan siswa dapat dengan baik.

Penggunaan dan pembelajaran IPA berkaitan dengan cara mencari tahu tentang alam secara sistematis sehingga IPA bukan hanya penguasaan kumpulan pengetahuan berupa fakta-fakta, konsep-konsep, atau prinsipprinsip saja tetapi juga merupakan suatu proses penemuan. Pendidikan IPA diharapkan dapat menjadi wahana bagi peserta didik untuk mempelajari diri sendiri dan alam sekitar. Yang menjadi masalah adalah bagaimana cara agar materi IPA dapat diterima siswa dengan baik dan maksimal, serta ada respon positif dari siswa.Mengajar IPA bukan sekedar menyampaikan materi kemudian selesai. Bukankah guru menginginkan siswa merasa nyaman, merasa senang terhadap materi yang disampaikan dengan metode yang tepat. Jika siswa sudah merasa nyaman dan senang dengan cara guru mengajar tentu materi yang kita sampaikan kepada siswa akan cepat diterima.

Kelas VII di MTs Negeri 2 Buleleng menjadi subjek penelitian karena memerlukan pembelajaran Kreatif, dan Inovatif. Kelas VII MTs Negeri 2 Buleleng sudah menerapkan kurikulum 2013. Berdasarkan Daftar Rekapitulasi Nilai UAS Mata Pelajaran Semester II Tahun 2019/2020 Siswa Kelas VII, MTs Negeri 2 Buleleng yang diberikan guru Kelas VIII dan Kelas VII, diketahui bahwa nilai terendah siswa, yaitu pada mata pelajaran IPA dengan nilai rata-rata kelas VIII adalah 7,0 dan nilai rata-rata kelas VII adalah 5,8. Kemudian dilakukan analisis nilai ulangan harian mata pelajaran IPA pada siswa Siswa kelas VII, dapat diketahui nilai terendah mata pelajaran IPA.

Kondisi ini menyebabkan perlunya media dalam pembelajaran. MTs Negeri 2 Buleleng memiliki fasilitas penunjang yang lengkap untuk menerapkan multimedia pembelajaran, tetapi multimedia pembelajaran yang terbatas membuat fasilitas tersebut tidak dimanfaatkan dengan baik. Fasilitas penunjang penerapan multimedia pembelajaran antara lain: Proyektor, Layar Proyektor, Laptop, dan Soundsystem. Di era informasi yang ditandai dengan kemajuan media komputer, memberikan kelebihan dalam kegiatan produksi media audiovisual. Contohnya Multimedia Pembelajaran.

Berdasarkan analisis karakteristik siswa diketahui bahwa siswa Kelas VII, MTs Negeri 2 Buleleng menyatakan belajar IPA sulit, lebih mudah memahami materi pelajaran dan lebih senang menggunakan media pembelajaran audiovisual daripada media cetak. Guru IPA kelas VII di MTs Negeri 2 Buleleng menyatakan bahwa siswa sangat sulit menjawab pertanyaan jika tidak terdapat kisi-kisi jawaban.

Berdasarkan uraian diatas, untuk membantu siswa dalam memahami bagaimana cara menjawab pertanyaan pada mata pelajaran IPA maka dipandang sangat perlu dikembangkan media pembelajaran yang inovatif yang dapat menunjang pembelajaran pada kelas VII di MTs Negeri 2 Buleleng, yaitu melalui Pengembangan Multimedia Pembelajaran Pada Mata Pelajaran IPA Untuk Meningkatkan Hasil Belajar Siswa 
Kelas VII di MTs Negeri 2 Buleleng Tahun Pelajaran 2019/2020 yang dapat memberikan media pembelajaran yang efektif, inovatif dan kreatif, serta meningkatkan kemampuan kognitif anak.

Melihat realita dilapangan tersebut, maka perlu dilakukan inovasi-inovasi dalam pembelajaran.Salah satu inovasi yang dimaksud adalah pengembangan multimedia pembelajaran. Multimedia pembelajaran ini mengefisienkan waktu belajar siswa. Diharapkan dengan dikembangkannya multimedia pembelajaran, siswa semakin termotivasi untuk belajar, rasa ingin tahu, mandiri, dan sesuai dengan tuntunan karakter yang baik bagi peserta didik. Oleh karena itu, dalam penelitian ini maka dilakukan suatu Pengembangan multimedia Pembelajaran pada mata pelajaran IPA kelas VII untuk meningkatkan hasil belajar siswa di MTs Negeri 2 Buleleng Tahun Pelajaran 2019/2020.

Adapun penelitian ini bertujuan untuk (1) medeskripsikan proses pengembangan multimedia pembelajaran (2) menguji kualitas multimedia pembelajaran, (3) mengetahui efektivitas multimedia pembelajaran pada mata pelajaran IPA.

\section{Metode}

Jenis penelitian pengembangan ini menggunakan tiga metode dalam pengumpulan data, yaitu (1) Pencatatan dokumen, (2) Kuesioner, dan (3) Tes. Penelitian ini menggunakan tiga metode pengumpulan data untuk menjawab permasalahan mengenai proses pengembangan Multimedia Pembelajaran, validitas dari pengembangan Multimedia Pembelajaran, dan efektivitas penggunaan Multimedia Pembelajaran terhadap hasil belajar siswa. Instrumen pengumpulan data adalah alat bantu yang dipilih peneliti dalam pengumpulan data. Dalam penelitian ini instrumen yang digunakan adalah laporan pencatatan dokumen, kuesioner, dan tes pilihan ganda.Menurut Agung (2012) metode pencatatan dokumen adalah metode pengumpulan data dengan cara mengumpulkan segala macam dokumen dan melakukan pencatatan secara sistematis. Metode kuesioner digunakan untuk mengukur validitas multimedia pembelajaran .Metode tes digunakan untuk menguji keefektivitasan penggunaan multimedia pembelajaran.

Instrumen berupa kuesioner yang digunakan untuk mengetahui validitas produk yang sudah dikembangkan terlebih dahulu diuji validitas butirnya oleh dua orang dosen yang berkompeten yaitu: (1) I Made Tegeh, S.Pd., M.Pd dan (2) Dewa Gede Agus Putra Prabawa, S.Pd., M.Pd. Kuesioner yang diuji validitasnya yaitu: (1) ahli isi mata pelajaran, (2) ahli media pembelajaran, dan (3) uji coba perorangan, (4) uji coba kelompok kecil dan (5) uji coba lapangan. Sejalan dengan hal tersebut Dick \& Carey (dalam Parmiti dan Prabawa, 2015:111) mengatakan bahwa evaluasi formatif terdiri atas empat tahapan, yaitu 1) review para ahli, 2) evaluasi satu-satu, 3) evaluasi kelompok kecil, dan 4) evaluasi lapangan.Sadiman (2012:182) "ada tiga tahapan evaluasi formatif, yaitu evaluasi satu lawan satu, evaluasi kelompok kecil, dan evaluasi lapangan. Hasil validasi instrumen untuk melakukan validasi produk yang telah dikembangkan, yaitu (1) validitas kuesioner isi diperoleh 94\% dengan kriteria sangat baik, (2) validitas kuesioner media diperoleh $86 \%$ dengan kriteria baik, (3) validitas kuesioner perorangan diperoleh 94,9\% dengan kriteria sangat baik, (4) validitas kuesioner kelompok kecil diperoleh 91,9\% dengan kriteria sangat baik, (5) validitas kuesioner lapangan diperoleh $92 \%$ sangat baik.

Data-data yang dikumpulkan melalui pelaksanaan evaluasi formatif dikelompokkan menjadi dua yaitu: (1) evaluasi tahap pertama berupa hasil review ahli bidang studi, dan hasil review ahli media pembelajaran. (2) data dari evaluasi tahap kedua berupa data hasil uji coba perorangan, data hasil coba kelompok kecil, dan hasil dari uji lapangan berupa hasil review siswa. Data-data yang dikumpulkan melalui pelaksanaan evaluasi sumatif yaitu data dari evaluasi uji efektivitas hasil belajar menggunakan tes objektif. Dalam penelitian pengembangan ini digunakan tiga teknik analisis data yaitu analisis deskriptif kualitatif, analisis deskriptif kuantitatif dan analisis statistik inferensial.(1) Teknik analisis deskriptif kualitatif ini digunakan untuk mengolah data hasil review ahli mata pelajaran, ahli media pembelajaran dan uji coba siswa. Teknik analisis data ini dilakukan dengan mengelompokkan informasi dari data kualitatif yang berupa masukan, tanggapan, kritik, dan saran perbaikan yang terdapat pada angket.Hasil analisis ini kemudian digunakan untuk merevisi produk yang dikembangkan. (2) Teknik analisis ini digunakan untuk mengolah data yang diperoleh melalui angket dalam bentuk deskripsi persentase. (3) Analisis statistik inferensial digunakan untuk mengetahui efektivitas produk terhadap hasil belajar siswa pada siswa kelas VII di MTs Negeri 2 Buleleng sebelum dan sesudah menggunakan produk pengembangan Multimedia Pembelajaran. Data uji coba kelompok sasaran dikumpulkan dengan menggunakan pre test dan post test terhadap materi pokok yang diuji cobakan. Hasil pre-test dan post-test kemudian dianalisis menggunakan ujit untuk mengetahui perbedaan antara hasil pre-test dan post-test.Sebelum melakukan uji hipotesis (uji-t berkorelasi) dilakukan uji prasyarat (normalitas dan homogenitas).

Subjek validasi pada tahap ini dilakukan oleh satu orang ahli isi mata pelajaran dan satu orang lai orang ahli media pembelajaran. (a) ahli isi bidang studi dalam penelitian ini adalah seorang guru di MTs Negeri 2 Buleleng. (b) ahli media pembelajaran dalam penilitian dianggap ahli mengembangkan media pembelajaran, nantinya akan diminta kesediaan dosen di program studi Teknologi Pendidikan.Subjek uji coba yaitu Kelas VII di MTs Negeri 2 Buleleng sebanyak 22 orang dengan berbagai karakteristik tingkat kepandaiannya, latar belakang, dan jenis kelamin. Setelah uji kelompok besar tentu media akan mendekatan kesempurnaan.Subjek efektivitas produk penelitian pengembangan Multimedia Pembelajaran yaitu siswa Kelas VII di MTs Negeri 2 Buleleng 
sebanyak 22 orang dengan berbagai karakteristik yang berbeda kepandainnya. Setelah itu melalui tahap uji coba kelompok besar media yang dibuat sudah mendekati sempurna.

Terdapat beberapa dasar pertimbangan dalam menentukan model pengembangan yang akan digunakan dalam membuat produk diantaranya: (1) model yang dipilih haruslah dipahami pengembang, (2) mengandung tahapan yang tidak terlalu kompleks juga tidak terlalu sederhana, (3) model dapat mengarahkan pengembang membuat produk secara efektif (Mahadewi dan Sukmana, 2015:86).

Proses pengembangan dilakukan dengan model pengembangan Luther. Pemilihan model ini didasari atas pertimbangan bahwa model Luther merupakan model desain pembelajaran yang paling generik dan dikembangkan secara sistematis dan berpijak pada landasan teoritis desain pembelajaran yang dikembangkan

Tahap pengembangan, Soenarto (dalam Tegeh dan Kirna, 2010:13) mengartikan "pengembangan sebagai suatu proses untuk menghasilkan dan memvalidasi produk-produk yang akan digunakan dalam penpembelajaran".Pada tahap pengembangan multimedia pembelajaran dari storyboard dan flowchart dikembangkan menjadi produk yang sesungguhnya, pada tahap ini menghasilkan produk multimedia pembelajara. Kegiatan yang pertama dilakukan adalah pengumpulan bahan atau materi bahan ajar, adapun bahan tersebut didapatkan dari buku ajar IPA kelas VII dan sumber lainnya yang relevan dengan materi yang diangkat pada multimedia pembelajaran. Multimedia setiap slide dikembangkan dengan aplikasi Adobe Flash CS 5.

Tahap implementasi, Pada tahap implementasi dimaksudkan untuk menerapkan efektivitas produk yang telah dibuat dilapangan. Dalam implementasi produk, hal-hal yang dilakukan yaitu dilakukan uji coba produk meliputi: ahli isi mata pelajaran, uji ahli media pembelajaran, uji coba perorangan, uji coba kelompok kecil dan uji coba lapangan. Untuk uji perorangan dilakukan di kelas yang lebih tinggi yaitu kelas VIII di MTs Negeri 2 Buleleng dengan jumlah responden sebanyak 3 orang siswa dengan hasil belajar tinggi, sedang dan rendah, sedangkan untuk uji coba kelompok kecil dilakukan di kelas yang sama dengan jumlah responden sebanyak 6 orang siswa dengan hasil belajar tinggi, sedang, dan rendah. Pada tahap ini multimedia pembelajaran yang dikembangkan kemudian dilakukan uji coba lapangan pada siswa kelas VII di MTs Negeri 2 Buleleng. Sebelum multimedia pembelajaran diimplementasikan pada siswa, terlebih dahulu siswa diberikan pre-test untuk mengukur pengetahuan awal siswa terhadap materi yang ada pada multimedia pembelajaran.Tes yang digunakan sebagai pre-test sudah melalui tahap uji coba ahli dan uji validitas butir tes di kelas VIII di MTs Negeri 2 Buleleng. Jumlah soal pre-test berjumlah 20 butir soal.Setelah mengerjakan soal pre-test kemudian dilanjutkan dengan implementasi multimedia pembelajaran. Implementasi multimedia pembelajaran dilakukan 1 kali pertemuan dengan alokasi waktu 90 menit.Pada saat implementasi guru menggunakan laptop, Proyektor yang telah difasilitasi sekolah sebagai media untuk memutar multimedia pembelajaran di dalam kelas.

Uji normalitas data dilakukan untuk memperlihatkan bahwa sampel benar-benar berasal dari populasi yang berdistribusi normal, sehingga perbedaan yang terjadi dapat mengakibatkan perlakuan bukan perbedaan yang ada pada sampel.

Uji normalitas dilakukan penyebaran soal tes pre-test dan post-test untuk mengetahui data hasil belajar siswa pada pembelajaran IPA tentang klasifikasi materi dan perubahannya yang terdiri dari dua tahapan yaitu, (1) penyebaran soal tes sebelum menggunakan multimedia pembelajaran (prettest), (2) Tahap penyebaran soal tes sesudah menggunakan multimedia pembelajaran (posttest).

Tabel 1. Hasil Uji Normalitas Pretest dan Posttest

\begin{tabular}{ccrrr}
\hline No & Hasil Belajar & LO & Lt & Ket \\
\hline 1. & Pretest & $-1,250$ & 0,1840 & Normal \\
2. & Posttest & $-0,035$ & 0,1726 & Normal \\
\hline
\end{tabular}

Hasil dari uji normalitas pretest diperoleh $\mathrm{L} 0=-1,250<0,1840$ maka $\mathrm{H} 0$ diterima, sehingga dapat disimpulkan bahwa sampel berasal dari populasi yang berdistribusi normal. Hasil dari uji normalitas posttest diperoleh $\mathrm{LO}=-0,035<0,1726$ maka $\mathrm{H} 0$ diterima, sehingga dapat disimpulkan bahwa sampel berasal dari populasi yang berdistribusi normal.

Tahap evaluasi, pada tahap akhir penilaian dilakukan untuk memvalidasi produk yang telah dibuat melalui uji ahli produk. Uji validasi produk bertujuan untuk menguji tingkat keajegan produk yang sudah dibuat, sedangkan uji efektivitas bertujuan untuk mengukur tingkat efektivitas produk yang dibuat.Pada setiap tahap pengembangan multimedia pembelajaran terdapat evaluasi dan revisi yang dilakukan demi perbaikan produk yang dihasilkan. Penilaian yang dilakukan yaitu penilaian formatif, yaitu penilaian yang dilakukan sepanjang proses pengembangan media, serta penilaian sumatif yaitu penilaian yang dilakukan untuk mengetahui efektif atau tidaknya produk yang dikembangkan dalam proses pembelajaran dengan melakukan uji efektivitas. Model Luther merupakan model desain pembelajaran yang paling generik dan dikembangkan secara sistematis dan berpijak pada landasan teoritis desain pembelajaran yang dikembangkan. Maka, proses pengembangan multimedia pembelajaran menggunakan model Luther, yaitu: concept, design, material collecting, assembly, testing, distribution. 


\section{Hasil dan Pembahasan}

Hasil validitas pengembangan multimedia pembelajaran menurut uji ahli isi mata pelajaran, uji ahli media pembelajaran, uji coba perorangan, uji coba kelompok kecil dan uji coba lapangan secara lebih rinci dapat disajikan pada tabel berikut.

Tabel 2. Hasil Uji Validitas Produk

\begin{tabular}{lcc}
\hline \multicolumn{1}{c}{ Subjek Uji Coba Multimedia } & $\begin{array}{c}\text { Hasil Validitas } \\
(\boldsymbol{\%})\end{array}$ & Keterangan \\
\hline Ahli isi mata pelajaran & 94 & Sangat baik \\
Ahli media pembelajaran & 86 & Baik \\
Uji coba perorangan & 94,9 & Sangat baik \\
Uji coba kelompok kecil & 91,9 & Sangat baik \\
Uji coba lapangan & 92 & Sangat baik \\
\hline
\end{tabular}

Hasil validitas pengembangan multimedia pembelajaran memperoleh persentase sangat baik. Melalui hasil uji validitas tersebut terdapat juga masukan, saran dan komentar yang diberikan para ahli dan subjek uji coba produk.masukan, saran dan komentar tersebut selanjutnya dijadikan pedoman dalam melakukan revisi produk sebelum produk diuji efektivitasnya ke lapangan.

Efektivitas pengembangan multimedia pembelajaran dilakukan dengan metode tes pilihan ganda. Soal tes pilihan ganda digunakan untuk mengumpulkan data nilai hasil belajar siswa sebelum dan sesudah menggunakan multimedia pembelajaran. Tujuan mengumpulkan data nilai siswa, agar dapat mengetahui tingkat efektivitas penggunaan multimedia pembelajaran terhadap peningkatan hasil belajar yang dilakukan dengan cara menggunakan uji t untuk sampel berkorelasi.

Sebelum menguji efektivitas produk pengembangan multimedia pembelajaran dengan menggunakan metode tes pilihan ganda, terlebih dahulu dilakukan uji coba instrumen tes hasil belajar dan uji prasyarat.Berdasarkan analisis, didapatkan $t_{\text {hitung }}$ sebesar $25,75 . t_{\text {hitung }}$ tersebut selanjutnya dibandingkan dengan $\mathrm{t}_{\text {tabel }}$ pada taraf signifikansi $5 \%$ dengan $\mathrm{db}=21$ adalah sebesar 2,080. Hasil tersebut menunjukkan bahwa $\mathrm{t}_{\text {hitung }}>$ $t_{\text {tabel, }}$ sehingga H0 ditolak dan H1 diterima.Ini berarti terdapat perbedaan yang signifikan (5\%) sebelum menggunakan multimedia Pembelajaran pada kelas VII di MTs Negeri 2 Buleleng Tahun Pelajaran 2019/2020 dan sesudah menggunakan multimedia Pembelajaran pada kelas kelas VII di MTs Negeri 2 Buleleng Tahun Pelajaran 2019/2020.

Hal ini menunjukkan bahwa multimedia Pembelajaran memberikan pengaruh signifikan terhadap hasil belajar IPA. Ini karena multimedia Pembelajaran memberikan kemudahan pada guru dalam penyampaian materi dan efisien dalam mencapai tujuan pembelajaran sehingga siswa memahami materi yang diberikan.

Dalam penelitian pengembangan ini produk yang dihasilkan adalah multimedia pembelajaran untuk kelas VII di MTs Negeri 2 Buleleng Tahun Pelajaran 2019-2020. Multimedia ini dikembangkan untuk memfasilitasi siswa kelas VII agar dapat belajar secara mandiri dan sesuai dengan kemampuan belajar masingmasing. Multimedia yang dikembangkan memuat materi IPA dan disertasi dengan gambar-gambar pendukung yang relevan dengan materi, siswa juga dapat melihat langsung gambar yang dipaparkan oada materi tersebut.

Validitas multimedia pembelajaran ini berdasarkan hasil evaluasi dari ahli yang meliputi; 1) uji ahli isi mata pelajaran, 2) uji coba ahli media pembelajaran, 3) uji coba perorangan, 4) uji coba kelompok kecil, dan 5) uji coba lapangan. Hal ini sesuai dengan pendapat Suartama (2016:4) "evaluasi sumatif dilakukan melalui tinjauan ahli (expert review). Ahli yang mengevaluasi media adalah ahli isi, ahli desain pembelajaran, ahli media". Selain itu menurut Sadiman (2012) "uji coba produk akan dilaksanakan dalam 3 (tiga) tahap yaitu uji coba perorangan, uji coba kelompok kecil, dan uji coba lapangan". Pembahasan uji coba produk adalah sebagai berikut.

Kualitas multimedia pembelajaran interaktif dilihat dari aspek isi mata pelajaran memperoleh persentase sebesar 96,00\% dan berada pada kategori sangat baik. Perolehan kualitas multimedia pembelajaran dengan kategori sangat baik dikarenakan multimedia ini telah menyajikan isi atau materi yang sesuai dengan tuntutan kompetensi inti, kompetensi dasar dan berasal dari sumber-sumber yang relevan. Penentuan materi juga tidak telepas dari silabus dan RPP yang digunakan. Materi yang disajikan pada multimedia diintegrasikan dengan gambar-gambar sebagai penjelas dari materi yang dicakup. Di akhir penyajian isi atau materi telah disediakan soal latihan yang relevan dengan materi sebagai tolak ukur pemahaman siswa dalam mempelajari materi yang disajikan.

Kualitas multimedia pembelajaran interaktif menurut ahli media pembelajaran dinyatakan valid dengan kualifikasi baik dengan perolehan persentase sebesar $86,00 \%$. Kriteria baik yang didapatkan dari ahli media pembelajaran karena dalam pengembangan multimedia, peneliti memperhatikan konsistensi dari multimedia yang sesuai dengan indikator dan tujuan pembelajaran.

Multimedia yang dikembangkan setelah melewati hasil review dari para ahli, yaitu ahli isi, dan ahli media pembelajaran, kemudian produk diuji cobakan kepada siswa. Tahap uji coba ini terdiri dari uji coba perorangan, kelompok kecil dan uji coba lapangan. 
Kualitas multimedia peembelajaran interaktif pada uji coba perorangan, uji coba kelompok kecil dan uji coba lapangan menunjukkan bahwa multimedia pembelajaran memiliki kualifikasi sangat baik dengan perolehan persentase masing-masing sebesar 94,90\% pada uji coba perorangan, 91,90\% pada uji coba kelompok kecil, dan 92,00\% pada uji coba lapangan. Perolehan kualitas sangat baik ini karena multimedia mampu memotivasi siswa dalam mengikuti kegiatan belajar mengajar. Multimedia juga memuat gambar-gambar yang mendukung materi, sehingga siswa menjadi lebih mudah memahami isi materi yang diterangkan. Selain itu bahasa yang digunakan dalam multimedia pembelajaran ini juga mudah dipahami oleh siswa.

Penelitian ini relevan dengan penelitian terdahulu oleh shinta kusuma wardani, dalam Pengembangan multimedia pembelajaran tutorial mata pelajaran IPA pokok bahasan sistem tata surya kelas VII MTs Raudatul Ulum, yang membuahkan hasil sangat baik berdasarkan uji validitas ahli materi dan ahli media serta uji efektivitasnya. Selain itu penelitian oleh Ni Made Penawati, I Made Tegeh, I Komang Sudarma dalam Pengembangan Multimedia Pembelajaran Interaktif Pada Mata Pelajaran Bahasa Indonesia Untuk Pembelajaran Mandiri Pada Siswa Kelas VIII, yang membuahkan hasil sangat baik berdasarkan uji ahli isi, uji ahli desain pembelajaran,uji ahli media pembelajaran, uji coba perorangan, uji coba kelompok kecil, dan uji coba lapangan serta uji efektivitasnya. Oleh karena itu dapat disimpulkan bahwa pengembangan multimedia pembelajaran untuk meningkatkan hasil belajar siswa kelas VII di MTs Negeri 2 Buleleng.

\section{Simpulan}

Berdasarkan hasil analisis data dan pembahasan pada penelitian ini, maka dapat disimpulkan sebagai berikut: (1) Proses pengembangan multimedia pembelajaran menggunakan model pengembangan Luther meliputi enams tahapan, yaitu (a) concept, (b) design, (c) material collecting, (d) assembly, (e) testing, (f) distribution. (2) multimedia pembelajaran valid dengan: (a) review ahli isi mata pelajaran menunjukkan multimedia pembelajaran dengan kualifikasi sangat baik (94\%), (b) review ahli media pembelajaran menunjukkan multimedia pembelajaran dengan kualifikasi baik (86\%), (c) uji coba perorangan multimedia pembelajaran dengan kualifikasi sangat baik (94,9\%), uji coba kelompok multimedia pembelajaran dengan kualifikasi sangat baik (91,9\%), dan uji coba lapangan multimedia pembelajaran berbasis dengan kualifikasi sangat baik (92\%). (3) Penggunaan multimedia pembelajaran efektif meningkatkan hasil belajar IPA pada kelas kelas VII di MTs Negeri 2 Buleleng Tahun Pelajaran 2019/2020 dengan perhitungan.

Berdasarkan hasil penelitian, pembahasan dan simpulan dapat diajukan beberapa saran sebagai berikut: (1) Bagi siswa, multimedia pembelajaran yang dikembangkan diharapkan dapat dijadikan media pembelajaran yang fleksibel sehingga dapat digunakan untuk belajar disekolah maupun dirumah. Multimedia pembelajaran yang dikembangkan untuk bisa digunakan pada Smartphone, PC, Tablet yang telah dilengkapi alat pemutar video, sehingga siswa dengan mudah belajar kapan saja, dan dimana saja. (2) Bagi guru, hasil pengembangan multimedia pembelajaran ini dapat dijadikan salah satu contoh media pembelajaran yang dapat meningkatkan motivasi belajar siswa didalam kelas dan digunakan terus-menerus. Diharapkan guru dapat termotivasi untuk mengembangkan media-media sejenis sehingga proses pembelajaran dikelas dapat didukung oleh media pembelajaran yang bervariasi.(3) Bagi sekolah, diharapkan agar selalu melakukan perawatan dan pergantian sarana dan pra-sarana yang ada di sekolah karena sarana-sarana yang ada sangatlah berperan sebagai alat untuk mendukung proses pembelajaran yang lebih baik lagi. (4) Bagi peneliti lain, disarankan untuk melakukan penelitian sejenis yaitu pengembangan multimedia pembelajaran dengan inovasi lainnya untuk siswa MTs/SMP kelas awal, karena siswa MTs/SMP kelas awal sangat termotivasi belajar menggunakan media audio visual, salah satunya multimedia pembelajaran. Hasil penelitian secara umum menunjukkan bahwa multimedia pembelajaran pada kualifikasi sangat baik dan dapat digunakan sebagai rujukan untuk melakukan penelitian sejenis dengan addobe flash.

\section{Daftar Pustaka}

Agung, Anak Agung Gede. 2012. Metodologi Penelitian Pendidikan. Singaraja: Undiksha. Dimyati dan Mudjiono. 1999. Belajar dan Pembelajaran, (Online), (diakses 19 Juli 2019). Mahadewi, Luh Putu Putrini dan Adrianus I Wayan Ilia Yuda Sukmana, 2015.Text-Based Programming : Konsep Dasar \& Aplikasi Pengembangan Produk Pendidikan. Yogyakarta: Graha Ilmu.

Mulyatiningsih, Endang. 2011. Metode Penelitian Terapan Bidang Pendidikan. Bandung: Alfabeta.

Sadiman, Arief., dkk. 2012. Media Pendidikan. Jakarta: PT. Rajagrafindo Persada.pdf.Diunduh pada tanggal 13 November 2018.

Sutirman. 2013. Media \& Model-model Pembelajaran Inovatif. Yogyakarta: Graha Ilmu.

Tegeh, I Made dan I Made Kirna. 2010. Metode Penelitian Pengembangan Pendidikan. Singaraja: Universitas Pendidikan Ganesha.

Tegeh, I Made dan I Made Kirna. 2013. "Pengembangan Bahan Ajar Metode Penelitian Pendidikan Dengan Addie Model". Jurnal Ikatan Alumni (IKA) Universitas Pendidikan Ganesha. Vol. 11, No. 1 (2013).Dalam https://ejournal.undiksha.ac.id/index.php/IKA/article/download/1145/1008.Diunduh pada tanggal 14 Juni 2018. 
Parmiti, Desak Putu dan Dewa Gede Agus Putra Prabawa. 2015. Buku Ajar Pengembangan Bahan Ajar. Singaraja: Undiksha.

Penawati, Ni Made. Dkk. 2015. "pengembangan multimedia pembelajaran intraktif mata pelajaran bahasa indonesia untuk pembelajaran mandiri siswa kelas VIII. Jurnal Jurusan Teknologi Pendidikan. Vol. 3 No. Dalam https://ejournal.undiksha.ac.id/index.php/JEU/article/view/5608. diunduh pada tanggal 10 januari 2019.

Wardani, Shinta Kusuma. 2019. "Pengembangan multimedia tutorial mata pelajaran IPA pokok bahasan tata surya kelas VII MTs Raudatul Ulum Karangploso. (skripsi Universitas Negeri Malang). Dalam jurnal http://journal2.um.ac.id/index.php/jktp/article/view/7370/39055. diunduh pada tanggal 10 januari 2019.

Wiana, W.2018. Interactive Multimedia-Based Animation: A Study of Effectiveness on Fashion Design Technology Learning. Seri 953. 2018. Pdf (diakses 23 Juni 2019). 